\title{
Global warming and health
}

\section{The changes expected in the world's climate will worsen health in many ways}

Last year was the hottest on record; eight of the 10 hottest years this century have occurred since 1980. Any division of opinion among scientists about global warming concerns only the extent and timing of the changes. Late last year the World Climate Conference discussed the policy implications and technical issues concerned in the light of the report of the United Nations Intergovernmental Panel on Climate Change. ${ }^{1}$

The "best guess" of the panel's scientists, assuming that emissions continue to grow at current rates, was of a realised $1^{\circ} \mathrm{C}$ rise in temperature above today's average by around 2025 , and about $3^{\circ} \mathrm{C}$ before the end of the next century, the upper estimate being $5^{\circ} \mathrm{C}$. (The realised rise at a given time accounts for only about $60-80 \%$ of the final rise because the thermal inertia of the oceans acts as a buffer.) These rates of warming are likely to be 10 to 100 times faster than any experienced in the past. ${ }^{2}$ The rise in temperature will be greater in middle and higher latitudes, particularly in winter, than in the tropics. The scientists also predict that if no steps are taken to limit emissions, by around 2030 effective carbon dioxide concentrations in the atmosphere will be twice those in preindustrial times. This takes into account the influence of other greenhouse gases. Carbon dioxide contributes about half of the greenhouse effect, chlorofluorocarbons, methane, and nitrous oxide accounting for most of the rest.

The picture is complicated by feedback mechanisms that could either dampen or accelerate change, but most seem to accentuate warming tendencies. An example is the possible release of methane from permafrost or from under the oceans as temperatures rise.

Regional changes in climate are difficult to predict, but in most models the increase in temperature is thought to reduce rainfall at the middle latitudes, particularly in the centre of continents. This could affect grain harvests and cause drought. Increases in world population are already outstripping small rises in the grain harvest, ${ }^{+}$so that changes in climate threaten increasing hunger in the Third World. Rice is a staple food for $60 \%$ of the world's population, but rice paddies are a source of methane, itself a potent greenhouse gas, and rice production too is vulnerable to changes in rainfall.

Global warming could cause the sea level to rise between $0 \cdot 3$ and $1 \cdot 1$ metres by 2100 , according to the intergovernmental panel. ${ }^{5}$ This may be a conservative estimate. ${ }^{6}$ The 10 countries most vulnerable to a rise in sea level include Bangladesh, Egypt, Pakistan, Indonesia, and Thailand, all of which have large, relatively poor populations. ${ }^{7}$ In Bangladesh floods caused the death of 300000 people in the 1970s, and the homes and livelihoods of 46 million are potentially threatened in the Nile delta in Egypt and the Ganges delta in Bangladesh. ${ }^{8}$ Here in England a one metre rise in sea level could wipe out many of our sandy beaches, salt marshes, and mud flats. ${ }^{9}$

Mortality may rise in some countries as a direct result of high temperatures. A study of the relation between temperature and mortality from coronary heart disease and stroke in a number of American cities showed an inverse relation between about $-5^{\circ} \mathrm{C}$ and $25^{\circ} \mathrm{C}$, with increases in mortality above and below this range. ${ }^{10}$ Associations between increases in daily mortality and short spells of relatively hot weather have been described in Greater London. ${ }^{11}$ The effect on overall mortality will depend on the degree to which deaths in winter are reduced, which is likely to vary according to the geographical location. Very elderly people will suffer the most from high temperatures, and their numbers are increasing in many developed countries.

Climate may also affect respiratory diseases. Acute bronchitis and bronchiolitis are more common in winter, as are pneumonia and exacerbations of chronic obstructive airways disease. Asthma and hay fever tend to peak in incidence in the summer months, according to general practice consultation figures, but there is a second peak of acute asthma in autumn. Hospital admissions tend to be more common in the last quarter of the year, probably related to viral infections. ${ }^{12}$

Climate may also influence communicable diseases. ${ }^{13}$ Many diseases are seen mainly in the tropics, though some of these-such as malaria, plague, typhus, and even yellow fever-occurred in the past in countries in the temperate zone. The insect vectors of many of these diseases and the pathogens they transmit are sensitive to temperature. For instance, the extrinsic incubation period of the four species of plasmodium that affect humans varies inversely with temperature, ${ }^{1+}$ as does that of the yellow fever virus. In Egypt water snails tend to lose their schistosomal infections during the cooler winter months. The effects of climate change on communicable diseases will not be limited to the Third World. In Australia a change in climate could lead to an increase in some mosquito-borne diseases such as Australian encephalitis and epidemic polyarthritis caused by the Ross River virus. ${ }^{15}$ Five of the numerous mosquito-borne diseases have been considered to be potential risks to the United States after a change in climate: malaria, dengue fever, encephalitides induced by arbovirus, yellow fever, and Rift 
Valley fever. Rocky Mountain spotted fever and Lyme disease could spread northwards. ${ }^{16}$

These effects of change in climate will occur against the background of a range of other global environmental threats such as depletion of stratospheric ozone, which is likely to cause increased skin cancer and cataract. ${ }^{17}$ Even more important, the world's population is increasing by three people every second. Between 90 and 100 million people will be added every year during the $1990 \mathrm{~s} .{ }^{18}$ In general, the biggest increases will be in the poorest countries. Competition for inadequate resources and rises in sea level are likely to lead to large numbers of environmental refugees. They in turn could spark social unrest and military conflict. Although the developed world will contribute only about $6 \%$ to the increase, even this is important because the carbon emissions from fossil fuels per head in a country such as the United States are more than 10 times greater than in Third World countries. ${ }^{19}$.

International efforts have been made to persuade each country to commit itself to decreasing carbon dioxide emissions by, say, $20 \%$ by the year $2000 .^{20}$ This move was strongly opposed in 1989 at an international meeting in The Netherlands by governments of the United States, Japan, the United Kingdom, and the Soviet Union. The European Community has agreed to stabilise emissions of carbon dioxide by the year 2000 but Britain has been granted a concession to overshoot the deadline by five years. Reductions in carbon emissions could be achieved by increasing energy efficiency and use of renewable sources of energy. Funding for such an initiative could come from military expenditure. In the United Kingdom some $40 \%$ of Britain's resource scientists and engineers direct their energies into military activity, but the budget of the government's Energy Efficiency Office is only $£ 15$ million annually and is being cut in real terms (although the funds for draughtproofing houses have recently been transferred from the Department of Employment, creating an apparent rise)..$^{21}$

More research is needed on the health implications of global environmental change,$^{22}$ and health professionals ${ }^{23}$ could also play an important part in persuading public opinion and governments that more resources, and some fundamental changes in policy, are needed to avert potential catastrophe.

ANDREW HAINES

Professor of Primary Health Care,

University College and Middlesex School of Medicine

Whittington Hospital,

London N19 5NF

Houghton JT, Jenkins GJ, Ephraums JJ, eds. Climate change. The IPCC scientific assessment. Cambridge: Cambridge University Press, 1990.

2 Huntley B. Lessons from climates of the past. In: Leggett J, ed. Global warming. Oxford: Oxford University Press, 1990:133-48.

3 Nisbet EG. Some northern sources of atmospheric methane: production, history and future implications. Canadian fournal of Earth Sciences 1989;26:1603-11.

4 Brown LR, Young E. Feeding the world in the nineties. In: Starke L, ed. State of the world 1990. A Worldwatch Institute report on progress towards a sustainable society. New York: W W Norton, 1990:59-78.

5 Warrick R, Oerlemans J. Sea level rise. In: Houghton JT, Jenkins GJ, Ephraums JJ, eds. Climate change. The IPCC scientific assessment. Cambridge: Cambridge University Press, 1990:263-81.

6 Titus JG. Sea level rise. In: Smith JB, Tirpak D, eds. The potential effects of global change in climate on the United States. Washington, DC: United States Environmental Protection Agency, on the United
1989:123-47.

7 United Nations Environment Programme. Criteria for assessing vulnerability to sea level rise: a global inventory of high risk areas. Delft, The Netherlands: Delft Hydraulics Laboratory, 1989.

8 Broadus J, Milliman J, Edwards S, et al. Rising sea level and damming of rivers: possible effects in Egypt and Bangladesh. In: Titus JG, ed. Effects of changes in stratospheric ozone and global climate. Vol 4. Sea level rise. Washington, DC: United States Environmental Protection Agency, 1986:165-89.

9 Boorman LA, Goss-Custard JD, McGrorty S. Climatic change, rising sea level and the British coast. London: HMSO, 1989. (Institute of Terrestrial Ecology Report No 1.)

10 Rogot E, Padgett SJ. Associations of coronary and stroke mortality with temperature and snowfall in selected areas of the United States, 1952-1966. Am $\mathcal{F}$ Epidemiol 1976;103:565-75.

11 MacFarlane A. Daily mortality and environment in English conurbations. 2. Deaths during summer hot spells in Greater London. Environ Res 1978;15:332-41.

12 Ayres JG. Meteorology and respiratory disease. Update 1990;40:596-605.

13 Gillett JD. Increased atmospheric carbon dioxide and the spread of parasitic disease. In: Cannin EV, ed. Parasitological topics: a presentation volume to P C Garmham, FRS, on his 80th birthday. Laurence, Kansas: Society of Protozoologists, 1981:106-11. (Special publication.)

14 Garnham PC. Factors influencing the development of protozoa in their arthropodan hosts. In Taylor AER, ed. Host parasite relationships in invertebrate hosts. Oxford: Blackwell Scientific, 1964:33-50.

15 Liehne PFS. Climatic influences on mosquito borne diseases in Australia. In: Pearman GR, ed. Greenhouse-planning for change in climate. Dickson, Australia: Division of Atmospheric Research, Commonwealth Scientific Industrial Research Organisation, 1989:624-37.

16 Longstreth JA. Human health. In: Smith JB, Tirpak D, eds. The potential effects of global change in climate in the United States. Washington, DC: United States Environmental Protection Agency, 1989:219-35.

17 Jones RR. Ozone depletion and cancer risk. Lancet 1987;ii:443-6.

18 Sadik N. The state of the world population 1990. New York: United Nations Population Fund, 1990 19 Flavin C. Slowing global warming. In: Starke L, ed. State of the world. A Worldwatch Institute report on progress towards a sustainable society. New York: W W Norton, 1990:17-38.

20 Eavis $\mathrm{P}$, Clarke M. Security after the Cold War-redirecting global resources. Bristol: Safer World Foundation, 1990

21 Fagan M. Boffin with the knack of conveying the energy conservation message. Independent 1990 Oct 15:21.

22 Haines A. The implications for health. In: Leggett J, ed. Global warming. Oxford: Oxford University Press, 1990:149-62.

23 McCally M, Cassel C. Medical responsibility and global environmental change. Ann Intern Med 1990;113:467-73.

\section{Diving into the unknown}

\section{A new code of practice should help}

In 1988 and 1989 at least 60 patients were admitted to spinal injuries units in the United Kingdom with tetraplegia as a result of diving injuries (unpublished observations). In many of these accidents the victims seemed unaware of the depth of the water and of the dangers of diving too steeply into too shallow water. The problem is often compounded by overconfidence, alcohol, and, we suspect, "macho" behaviour in young men. Some people, however, are rendered tetraplegic simply as a result of a running plunge into the surf, striking their heads on a sand bar. We are concerned that many people are unaware of the dangers of diving and that in many cases these accidents are entirely preventable.

Almost half these injuries occurred in swimming pools, about a third in the sea, and the remainder in rivers, lakes, or ponds. Overwhelmingly the victims were young, with an average age of 24 , and almost all were men. The peak incidence of injury was in the summer, over half occurring from June to August. At least a third of the victims had drunk alcohol before their dive. Over a third sustained their injury in Britain; abroad, the most common locations were Spain and Greece.

Most injuries occur when the head either strikes the bottom of a pool, the sea, or river bed or hits a submerged object such as a rock. The bony injury resulting is nearly always a crush fracture of a lower cervical vertebra, usually $\mathrm{C} 5$, associated with retropulsion of the vertebral body and direct injury to the spinal cord.

The number of serious diving injuries is probably underestimated. Some people who develop tetraplegia due to a dangerous dive almost certainly drown if help is not at hand to rescue them. Relevant figures are not available, largely because the signs of cervical spine injury are easily missed at necropsy unless cervical radiographs have been taken.

In 1965 the Amateur Swimming Association informed local authorities that most diving installations were unsafe and did not conform to international guidelines. ${ }^{1}$ Within a few months 